\title{
PENGARUH INTERFERENSI DAN REHEARSAL TERHADAP RETENSI BELAJAR BAHASA INGGRIS PADA SISWA MADRASAH TSANAWIYYAH
}

\section{THE EFFECT OF INTERFERENCE AND REHEARSAL TOWARD ENGLISH RETENTION AMONG STUDENTS OF THE ISLAMIC JUNIOR HIGH SCHOOL STUDENTS}

\author{
Sri Wiranti Wahidah \\ Sukarti \\ Hazhira Qudsyi
}

Fakultas Psikologi dan IImu Sosial Budaya, Universitas Islam Indonesia Yogyakarta E-mail: sriwirantiwahidah@yahoo.co.id

\begin{abstract}
This research was aimed to examine the effect of interference and rehearsal toward English retention among 8th grade students of Islamic Junior High School "Sunan Pandanaran". The hypotesis is there' difference of mean in achievement of English test among three gorups. The subject of research are 51 student dividing in three groups: experiment 1, experiment 2, and control group. Data was analysed by one way ANOVA. Based on the result of analysis found $p=0.00$. It means there is the difference of mean in achievement of English test among students who received the intervention and who did not.
\end{abstract}

Key Words: Interference, rehearsal, retention on Englsih subject.

\begin{abstract}
ABSTRAK
Penelitian eksperimental ini bertujuan untuk menguji pengaruh interferensi dan rehearsal terhadap retensi Bahasa Inggris pada siswa kelas VIII MTs Sunan Pandanaran. Hipotesis penelitian adalah ada perbedaan rata-rata nilai tes prestasi bahasa Inggris pada tiga kelompok tersebut. Penelitian mengambil subjek 51 siswa kelas VIII MTs Sunan Pandanaran yang terbagi ke dalam tiga kelompok penelitian: kelompok eksperimen 1, eksperimen 2 dan kelompok kontrol. Analisis data dilakukan dengan metode statistik one way ANOVA. Berdasarkan hasil analisis diperoleh p sebesar 0,00 yang berarti ada perbedaan rata-rata nilai tes prestasi bahasa Inggris antara siswa yang diberi interferensi dan siswa yang diberi rehearsal.
\end{abstract}

Kata kunci: Interferensi, rehearsal, retensi pada pelajaran bahasa Inggris 
Dewasa ini perkembangan dunia yang telah dijarkan. Namun, efektifnya pendidikan semakin pesat dirasakan oleh berbagai kalangan, terutama pihakpihak yang terlibat langsung dalam kegiatan tersebut, seperti guru dan murid. Pesatnya perkembangan ini ditandai dengan adanya upaya pemerintah untuk senantiasa meningkatkan kualitas pendidikan dengan cara memberikan syarat atau standar nilai kelulusan tertentu bagi para siswa tingkat akhir. Pada tahun 2008, pemerintah menetapkan standar kelulusan 5,25 untuk tingkat menengah pertama dan sederajat (SMP/MTs). Tahun 2009, standar nilai yang ditetapkan pemerintah naik menjadi 5,50, dan sekarang siswa yang lulus pada tahun 2010 syarat kelulusan adalah memiliki nilai rata-rata minimal 5,50 untuk seluruh mata pelajaran yang diujikan dengan nilai minimal 4,00 untuk paling banyak dua mata pelajaran dan minimal 4,25 untuk mata pelajaran lainnya. Perkembangan ini terasa sangat signifikan tiap tahunnya karena pemerintah menargetkan setiap siswa yang lulus memiliki kompetensi yang tinggi dalam dunia pendidikan dengan harapan dapat mengoptimalkan kualitas sumber daya manusia di negeri ini (Kompas, 2010).

Keberhasilan siswa dalam belajar umumnya diukur dari nilai-nilai yang didapatkan dalam ujian baik yang berskala lokal ataupun nasional. Nilai-nilai yang diperoleh siswa ini merupakan gambaran seberapa besar siswa menguasai konsep suatu metode pembelajaran tidak bisa dilihat dari penguasaan konsep saja. Perlu adanya analisis lebih lanjut apakah konsep-konsep yang dipelajari siswa dapat melekat pada ingatan ataukah mudah terlupakan karena pembelajaran yang dilakukan hanya berupa transfer hafalan belaka.

Idealnya, konsep-konsep yang siswa pelajari dapat melekat kuat pada ingatannya. Konsep-konsep yang dipahami secara baik oleh para siswa dari pembelajaran, dapat disimpan dalam ingatan atau memori yang kemudian akan dipergunakan pada saat diperlukan seperti menjawab pertanyaan ketika ujian berlangsung. Kemampuan siswa untuk dapat menyimpan konsep-konsep, informasi atau materi yang diajarkan ini disebut retensi. Retensi akan meningkat ketika sel-sel saraf terstimulasi sehingga sel-sel saraf tersebut dapat berkembang. Sel-sel saraf ini berkembang melalui interaksi antara neuron-neuron. Selsel saraf akan menjadi terhubung dan termilelinasi untuk memudahkan dalam mengingat informasi (Afiatin, 2001). Kualitas ingatan terhadap informasi yang diterima dikenal dengan istilah retensi. Sedangkan faktor retensi, sebagai indikator keberhasilan dan gambaran tentang kualitas suatu pembelajaran, kurang mendapat perhatian dari berbagai pihak yang telibat dalam bidang pendidikan (Alsa, 1996). 
Berdasarkan hasil observasi dan wawancara dengan beberapa orang guru MTs Sunan Pandanaran yang mengampu mata pelajaran yang akan diujikan pada ujian nasional (Matematika, IPA, bahasa Inggris, dan bahasa Indonesia), diperoleh informasi bahwa pada tahun ajaran 2009-2010 nilai rata-rata terendah yang diperoleh siswa ada pada pelajaran bahasa Inggris. Keadaan ini berlangsung selama berberapa tahun terakhir dan mengalami penurunan nilai rata-rata dari taun ke tahun. Perbandingan nilai dari keempat mata pelajaran yang diujikan antara lain bahasa Indonesia dan Matematika memperoleh nilai rata-rata yang sama yaitu 8,27 (untuk Matematika turun 0,73 dari tahun sebelumnya, sedangkan bahasa Indonesia tetap). Nilai rata-rata untuk pelajaran Ilmu Pengetahuan Alam adalah 8,58 (naik 1,02 dari tahun sebelumnya). Sementara pelajaran bahasa Inggris memperoleh nilai rata-rata 6,88 dengan nilai terendah 3,40. Jika dibandingkan dengan tahun ajaran 2008-2009, nilai tersebut mengalami penurunan, nilai rata-rata bahasa Inggris pada tahun ajaran 2008-2009 adalah 7,32 dengan nilai terendah 4,80.

Berdasarkan hasil wawancara dengan beberapa siswa MTs Sunan Pandanaran, diperoleh informasi bahwa mayoritas siswa menggunakan metode menghafal dalam mempelajari materi bahasa Inggris. Namun, kemampuan menghafal ini tidak selamanya dipandang efektif oleh pihak guru. Dalam beberapa ujian, siswa justru mengalami kesulitan dalam membentuk konsep-konsep yang telah dipelajari dan mengaitkan apa yang dipikirkan untuk menyelesaikan soal-soal bahasa Inggris yang diujikan. Tampak bahwa informasi atau materi pembelajaran yang sudah diterima dan disimpan dalam ingatan siswa sering mengalami masalah atau kendala ketika akan dipergunakan kembali.

Masalahyang menyebabkan informasi yang sudah diterima dan disimpan dalam ingatan menjadi terhambat saat digunakan dikenal sebagai lupa (Solso, Maclin, \& Maclin, 2008). Hambatan dalam berfikir ini dapat diketahui dari reaksi siswa yang mengalami kesulitan dalam membentuk konsep, mengaitkan apa yang dipikirkan dan memecahkan masalahnya. Seorang siswa yang memiliki hambatan dalam mengingat, akan mengalami kesulitan untuk mengingat informasi yang telah siswa dengar dan siswa lihat, sedangkan daya ingat merupakan salah satu syarat dalam proses belajar.

Ketika banyak hal yang telah disimpan dalam ingatan sulit untuk diproduksikan lagi, hal ini dikenal sebagai lupa (Syamsudin dalam Alsa, 1996). Siswa yang lupa terhadap bahan pelajaran yang dipelajari sebelumnya membawa dampak negatif. Kelupaan selain dapat menyebabkan kesukaran bagi dirinya untuk dapat memahami bahan pelajaran berikutnya, juga menyebabkan hasil ulangan atau ujianya jelek, yang akibatnya bisa tidak naik kelas atau tidak lulus ujian (Alsa, 1996). 
Pertanyaan yang sering muncul dalam pikiran orang yang belajar adalah "Mengapa seseorang mengingat sesuatu dan melupakan sesuatu yang lain? Mengapa seseorang dapat mengingat hal sepele yang terjadi setahun yang lalu namun lupa terhadap suatu yang penting yang terjadi kemarin?" Solso dkk (2008) menjelaskan bahwa hampir sebagian besar peristiwa yang dilupakan terjadi karena informasi dalam STM (ShortTerm Memory) mengalami pemudaran dan tidak ditransfer ke LTM (Long-Term Memory). Akan tetapi, lupa juga bisa terjadi dikarenakan seseorang kehilangan kemampuan di dalam mengingat informasi yang telah ada di dalam LTM karena informasi yang telah tersimpan tidak diakses dalam jangka waktu yang lama dan memudar secara alamiah.

Salah satu alasan penting seseorang mengalami lupa adalah karena faktor interferensi. Interferensi adalah adanya informasi baru yang bercampur dengan atau tergeser oleh informasi lain (Solso dkk, 2008). Berdasarkan hasil wawancara dengan beberapa siswa MTs Sunan Pandanaran, diketahui bahwa mayoritas dari siswa mengalami kelupaan karena banyaknya materi yang telah dipelajari oleh siswa dalam rentang waktu tertentu dan tidak ada keterkaitan antara satu pelajaran dengan pelajaran yang lain. Untuk mengetahui sejauh mana pengaruh interferensi dalam belajar, peneliti melakukan wawancara singkat terhadap beberapa siswa kelas VIII MTs Sunan
Pandanaran Yogyakarta dan diperoleh informasi sementara bahwa interferensi dari pelajaran lain menyebabkan kelupaan.

Sebagai contoh, salah satu siswa kelas VIII $F$ menceritakan pengalaman belajarnya pada semester genap yang lalu. Siswa mengalami kebingungan ketika dalam satu hari yang bersamaan ada dua materi yang akan diujikan, bahasa Inggris dan Biologi. Siswa menghafalkan kosakata dan materi berbahasa Inggris kemudian siswa mempelajari materi Biologi. Ketika pelajaran bahasa Inggris diujikan, siswa melupakan hampir sebagian kosakata dan materi yang telah dihafalkan.

Meskipun seseorang dalam belajar mengalami peristiwa interferensi sehingga mengalami hambatan dalam belajar, namun ada faktor lain yang dapat mengakibatkan seseorang menjadi ingat akan informasi yang telah dipelajari pada waktu mempelajari informasi yang sama, yaitu rehearsal. Rehearsal adalah seseorang yang mempelajari informasi baruakan memantapkan ingatan mengenai informasi yang telah dipelajari (Solso, dkk., 2008). Ketika siswa mempelajari materi bahasa Inggris, kemudian mengulanginya di asrama, materi tersebut melekat dalam ingatan siswa selama beberapa waktu. Menghafal dan mempelajari kembali materi yang telah diajarkan merupakan cara yang dominan dilakukan siswa MTs Sunan Pandanaran dalam belajar. Namun mengapa rata-rata nilai rapor dan nilai ujian pada mata pelajaran bahasa Inggris lebih rendah jika dibandingkan 
dengan nilai mata pelajaran lain yang diujikan dalam ujian nasional? Apakah interferensi selamanya akan menurunkan retensi seseorang dan apakah selamanya rehearsal selamanya akan meningkatkan retensi seseorang? Inilah yang akan menjadi fokus dalam penelitian kali ini.

Mayoritas siswa MTs Sunan Pandanaran dikatakan sebagai usia remaja. Usia remaja merupakan usia di mana seorang individu telah memiliki kemampuan kognitif yang lebih sempurna daripada usia anak-anak. Kognisi seorang remaja telah mampu berfikir lebih sistematis, logis, abstrak, dan kompleks. Idealnya, seorang remaja mampu membentuk konsep yang dipelajarinya dan mengaitkan konsepkonsep tersebut dalam kegiatan belajar. Dalam mempelajari bahasa Inggris, siswa seharusnya mampu memilih objek materi yang tepat yang dapat digunakan untuk menjawab atau memecahkan soal-soal yang diberikan. Setelah siswa mampu memilih objek materi yang tepat, siswa akan mengaitkan konsep tersebut sesuai konteks soal yang diujikan sehingga siswa dapat memecahkan soal tersebut dengan benar.

Teori kognitif Piaget (Santrock, 1983) menyebutkan bahwa manusia melewati empat tahapan kognitif dalam memahami dunia. Tahap pertama, sensori motor (sensori motor stage) berlangsung dari kelahiran hingga 2 tahun. Anak mulai mengoordinasikan pengalaman sensor (seperti melihat dan mendengar) dengan tindakan motorik fisik. Tahap praoperasional (praoperational stage) usia 2-7 tahun, merupakan tahap kedua. Anak mulai melukiskan dunia dengan kata-kata dan gambar-gambar, pikiran simbolis melampaui hubungan sederhana antara informasi sensor dan tindakan fisik. Tahap ketiga adalah tahap operasional konkret (concrete operational stage) berlangsung pada usia 7-11 tahun. Anak dapat melaksanakan operasi, dan penalaran logis menggantikan pemikiran intuitif sejauh pemikiran tersebut dapat diterapkan dalam contoh-contoh yang spesifik atau konkrit. Tidak dapat dibayangkan langkah-langkah yang diperlukan untuk menyelesaikan suatu persamaan aljabar, yang terlalu abstrak untuk dipikirkan pada tahap perkembangan ini. Tahap keempat adalah tahap operasional formal (formal operational stage) usia 11-15 tahun. Pada tahap ini individu melampaui dunia nyata, pengalaman-pengalaman konkrit dan berfikir secara abstrak dan lebih logis. Remaja dapat menggembangkan gambaran yang lebih ideal. Dalam memecahkan masalah, individu mampu berfikir lebih sistematis, mengembangkan hipotesis tentang mengapa sesuatu terjadi, kemudian menguji hipotesis ini dengan cara deduktif.

Piaget menyatakan bahwa pemikiran operasional formal berlangsung pada usia remaja, antara usia 11 hingga 15 tahun. Pemikiran operasional formal lebih abstrak dari pada pemikiran anak. Ketika remaja mampu berfikir lebih abstrak dan idealis, mereka juga mampu 
berfikir lebih logis (Kuhn dalam Santrock, 1983). Remaja memiliki kemampuan kognitif untuk mengembangkan hipotesis mengenai cara pemecahan masalah, kemudian mereka menarik simpulan secara sistematis, atau menyimpulkan pola mana yang akan diterapkan dalam memecahkan masalah. Sebaliknya, anak cenderung memecahkan masalah secara coba-coba (trial and error).

Lain halnya dengan mayoritas siswa MTs Sunan Pandanaran. Siswa menunjukkan reaksi yang mengindikasikan adanya hambatan dalam menggunakan materi yang dipelajari baik secara dalam membentuk ataupun mengaitkan konsep-konsep yang telah dipelajari. Berdasarkan teori tahapan perkembangan kognitif, di usia antara 11 sampai 15 tahun seharusnya siswa mampu berfikir logis, sistematis dan abstrak. Namun pada kenyataannya, siswa tampak bingung ketika mendapatkan soal bahasa Inggris. Hal ini terjadi karena mayoritas siswa tidak familiar dan tidak terbiasa menggunakan bahasa Inggris dalam kehidupan sehari-hari sehingga tidak ada gambaran yang jelas dalam benak siswa mengenai meteri yang disampaikan oleh pihak guru. Ketidakpahaman tersebut diikuti dengan banyaknya informasi atau materi yang siswa terima dalam interval waktu tertentu, antara masuknya informasi sampai dengan informasi tersebut digunakan kembali, sehingga jejak-jejak ingatan mengenai materi bahasa Inggris mengalami penggaburan atau dikenal dengan istilah memory traces (Solso dkk, 2008).

Kemampuan mengingat siswa atau dalam hal ini dikenal dengan istilah retensi. Retensi dapat diketahui melalui pemberian tes kognitif yang hasilnya merujuk pada prestasi siswa dalam mengerjakan tes tersebut, contohnya tes prestasi belajar. Tes prestasi belajar adalah tes yang tersusun terencana untuk mengungkap performansi maksimal subjek dalam menguasai bahan atau materi yang telah diajakan. Dalam kaitannya dengan pendidian formal di kelas, tes prestasi belajar dapat berbentuk ujian atau ulangan harian, dan ujian semester.

Banyak siswa yang berharap agar dapat mengingat materi atau bahan pelajaran yang sudah dipelajari secara capat, tepat, dan mudah sehingga konsep yang dipahami secara baik oleh siswa dari pembelajaran dapat disimpan dalam ingatan atau memori yang kemudian akan dipergunakan pada saat diperlukan. Akan tetapi banyak siswa menjadi lupa terhadap bahan pelajaran, bahkan yang baru saja dipelajari. Lupa terhadap sesuatu, sebagai lawan dari kemampuan mengingat (retensi), merupakan permasalahan yang sifatnya universal, dapat terjadi pada siswa manapun. Materi atau bahan yang dilupakan siswa bisa bervariasi, mulai dari informasi-informasi faktual, simbol-simbol, pengertian, konsep, prinsip dan sebagainya. Siswa yang lupa terhadap bahan pelajaran yang 
dipelajari sebelumnya membawa dampak negatif, kerena selain dapat menyebabkan kesukaran bagi dirinya untuk dapat memahami bahan pelajaran berikutnya, juga menyebabkan hasil ulangan atau ujiannya jelek, yang akibatnya bisa tidak naik kelas atau tidak lulus ujian. Banyak faktor yang menyebabkan siswa menjadi lupa, dan banyak cara untuk meningkatkan kemampuan mengingat. Penelitian ini bermaksud menguji pengaruh interferensi dan rehearsal terhadap retensi pada pelajaran bahasa Inggris siswa kelas VIII MTs Sunan Pandanaran. Hipotesis penelitian yang diajukan adalah ada perbedaan pengaruh rehearsal dan interferensi dalam meningkatkan kemampuan mengingat (retensi) siswa pada pelajaran Bahasa Inggris siswa kelas VIII MTs. Sunan Pandanaran.

\section{METODE PENELITIAN}

\section{Subjek Penelitian}

Subjek penelitian ini adalah siswa kelas VIII MTs Sunan Pandanaran Yogyakarta yang berusia 14-15 tahun yang terbagi ke dalam tiga kelompok penelitian: kelompok eksperimen 1, eksperimen 2 dan kelompok kontrol. Teknik random yang digunakan adalah random assignment, yaitu random dilakukan pada populasi yang homogen, dilakukan dengan cara mengundi nama atau nomor subjek dalam populasi.

\section{Desain penelitian}

Desain penelitian yang digunakan dalam penelitian ini adalah BetweenSubject-Design yang dikenalkan oleh R.A Fisher pada tahun 1925 dengan desain Post Test Only Control Group Design (Seniati, Yulianto, \& Setiadi, 2009). Desain ini membagi subjek dalam tiga kelompok secara random, menjadi kelompok eksperimen 1, kelompok eksperimen 2, dan kelompok kontrol. Pengaruh variabel bebas (interferesi dan rehearsal) terhadap variabel tergantung (retensi) dapat diketahui dari perbedaan skor variabel tergantung antara kelompok-kelompok subjek yang diberikan perlakuan yang berbeda. Format eksperimen yang akan digunakan untuk mengetahui pengaruh interferensi dan rehearsal terhadap retensi adalah sebagai berikut:

Tabel 1. Rancangan Eksperimen

$$
\begin{array}{llll}
\text { KE } & \text { R } & X & O \\
\cline { 2 - 3 } & \text { RK } & & \text { O }
\end{array}
$$

\begin{tabular}{cccc}
\hline Kelompok & Belajar $\left(\mathbf{9 0}^{\prime}\right)$ & Belajar $\left(\mathbf{9 0}^{\prime}\right)$ & Tes retensi $\mathbf{( 4 5}^{\prime}$ ) \\
\hline Eksperimen $\mathbf{1}$ & Bahasa Inggris & Bahasa Inggris & Bahasa Inggris \\
Eksperimen 2 & Bahasa Inggris & Matematika & Bahasa Inggris \\
Kontrol & Bahasa Inggris & Istirahat & Bahasa Inggris \\
\hline
\end{tabular}




\section{Metode Pengumpulan Data}

Retensi siswa diukur dengan menggunakan alat tes prestasi (achievement test) bahasa Inggris yang dibuat oleh guru yang bersangkutan berdasarkan silabus, yang terdiri dari 4 materi ajar, yaitu simple present, simple past, present countinuous tense, dan present perfect tense. Awalnya seluruh subjek dimasukkan kedalam kelompok secara random, sehingga diperoleh tiga kelompok yaitu kelompok eksperimen 1 dengan perlakuan rehearsal, kelompok eksperimen 2 sebagai kelompok kontrol dan kelompok eksperimen 3 sebagai kelompok yang diberi perlakuan interferensi. Kekuatan retensi terhadap belajar bahasa Inggris tercermin melalui perbandingan skor tes bahasa Inggris "tenses" antara tiga kelompok subjek. Semakin tinggi skor bahasa Inggris yang diperoleh siswa melalui tes "tenses", maka semakin tinggi retensi siswa pada pelajaran bahasa Inggris.

\section{Prosedur Penelitian}

Persiapan. Persiapan penelitian meliputi:

1. Penyusunan materi, dilakukan berdasarkan materi yang paling sulit dipelajari siswa.

2. Filterisasi subjek. Proses penyaringan subjek dilakukan dengan cara subjek menjawab beberapa pertanyaan pada selembar kertas yang diberikan oleh eksperimenter. Subjek yang memenuhi syarat akan dipilih secara random untuk dimasukkan dalam kelompok-kelompok eksperimen.

3. Randomisasi subjek. Random berdasarkan absen ganjil genap lalu mengumumkan hasil pembagian kelompok sebelum penelitian dilaksanakan.

4. Try out soal. Try out dilakukan di dua sekolah dengan waktu yang berbeda.

5. Analisis psikometri dan revisi alat tes (indeks kesukaran aitem dan konsistensi internal belah dua spearman brown).

6. Alat tes revisi selesai dibuat dan siap untuk digunakan dalam penelitian.

Pelaksanaan. Adapun pelaksanaan pemberian intervensi adalah sebagai berikut:

KE1. Urutan 1: Belajar bahasa Inggris

Urutan 2: Belajar bahasa Inggris

Urutan 3: Pemberian tes

KK Urutan 1: Belajar bahasa Inggris

Urutan 2: Istirahat

Urutan 3: Pemberian tes

KE2. Urutan 1: Belajar bahasa Inggris

Urutan 2: Belajar matematika

Urutan 3: Pemberian tes

Evaluasi. Scoring berdasarkan jumlah jawaban yang benar.

\section{Teknik Analisis Data}

Teknik analisis data untuk menguji hipotesis dalam penelitian ini adalah teknik Analisis One Way Anova. One Way Anova digunakan untuk mengetahui 
ada atau tidaknya perbedaan ratarata untuk lebih dari dua kelompok sampel yang tidak berhubungan, yang dalam perhitungannya dibantu dengan perangkat Sistem SPSS 11 for Windows (Priyatno, 2010).

\section{HASIL PENELITIAN}

Hasil penelitian menunjukkan bahwa ada perbedaan rata-rata nilai bahasa Inggris pada siswa yang diberi interferensi dan siswa yang diberi rehearsal. Siswa yang diberi rehearsal memiliki retensi yang lebih tinggi dibandingkan dengan siswa yang diberi interferensi.

\section{Hasil Uji Asumsi}

Uji asumsi menggunakan uji homogenitas. Uji homogenitas digunakan untuk mengetahui homogenitas retensi pada kelompok eksperimen dan kelompok kontrol. Data dikatakan homogen bila $p>0,05$. Hasil analisis di peroleh data homogenitas $(p=0,0,668$ dan $\mathrm{p}>0,05)$. Hal ini menunjukkan tidak ada perbedaan varian antar kelompok (ketiga varian adalah sama, varian kelompok 1, 2, dan kontrol).

\section{Hasil Uji Hipotesis}

Langkah selanjutnya adalah uji hipotesis yang akan dilakukan dengan menggunakan teknik One Way ANOVA menggunakan program SPSS 11 for Windows. Hasil analisis menunjukkan ada perbedaan rata-rata nilai bahasa
Inggris antar ketiga kelompok tersebut. Siswa yang mendapatkan rehearsal memiliki nilai rata-rata yang lebih tinggi. Rata-rata jawaban benar pada tes bahasa Inggris yang diperoleh kelompok rehearsal adalah 20,2, kelompok interferensi 13,2 dan kelompok kontrol 18.

\section{PEMBAHASAN}

Penelitian ini bertujuan untuk mengetahui pengaruh interferensi dan rehearsal terhadap retensi pelajaran bahasa Inggris pada siswa kelas VIII. Berdasarkan analisis yang telah dilakukan sebelumnya, diperoleh hasil yang menunjukkan adanya pengaruh interferensi dan rehearsal terhadap retensi pelajaran bahasa Inggris pada siswa kelas VIII. Artinya, siswa yang diberi rehearsal memiliki retensi yang lebih tinggi pada mata pelajaran bahasa Inggris daripada siswa yang diberi interferensi yang ditunjukkan dengan nilai rata-rata siswa pada pelajaran bahasa Inggris. Dengan demikian, hipotesis yang telah penulis ajukan sebelumnya dapat diterima.

Retensi atau ingatan terhadap pengetahuan yang dipelajari merupakan faktor yang penting dalam suatu proses belajar. Retensi mengacu pada tingkat di mana materi (informasi) yang telah dipelajari masih melekat dalam ingatan. Materi bahasa Inggris yang diberikan oleh guru ditangkap oleh panca indera. Informasi yang dibawa oleh pancaindera 
tersebut kemudian disimpan sementara dalam memori sensoris. Proses penyimpanan informasi berupa materi bahasa Inggris dalam memori sensoris akan melalui jalur-jalur saraf sensoris yang berlangsung dalam jangka waktu yang sangat pendek. Pada saat siswa menerima informasi melalui panca indra yang dimiliki, informasi itu diubah dalam bentuk impuls-impuls neural dan dihantarkan ke bagian-bagian tertentu dari otak. Proses ini terjadi dalam sepersekian detik.

Menurut Craik dan Lockhurt (Solso dkk, 2007), kapasitas memori jangka pendek sangat terbatas untuk menyimpan sejumlah materi dalam jangka waktu tertentu. Sejumlah meteri baru yang masuk akan mendapat perhatian (attention) penuh dan dianalisis hanya dalam level yang dangkal akan mudah dilupakan. Sedangkan materi yang diproses secara mendalam (yang diberikan perhatian khusus) dianalisis secara menyeluruh dan diperkaya dengan asosiasi-asosiasi atau citra-citra bertahan lama dalam ingatan. Selama penelitian berlangsung, siswa menerima materi yang sama pada waktu yang bersamaan, kemudian kelompok eksperimen 1 diberi pengulangan sehingga materi bahasa Inggris yang diterima dapat dipelajari secara lebih mendalam. Melalui pemberian contoh dan tanya jawab siswa memiliki ingatan yang lebih tinggi jika dibandingkan dengan kelompok lain.
Peterson dan Intons-Peterson (Solso dkk, 2008) mengatakan bahwa pengulangan atau rehearsal dapat mempertahankan informasi dalam memori jangka pendek. Informasi yang diperoleh secara total, mendalam, dan sering diulang merupakan stimulasi bagi sel-sel saraf. Sel-sel saraf akan dapat berkembang dengan baik jika terstimulasi. Sel-sel saraf ini berkembang melalui interaksi antara neuron-neuron. Melalui pengulangan atau rehearsal, selsel saraf akan menjadi terhubung dan termilelinasi untuk memudahkan dalam mengingat informasi (Afiatin, 2001). Semakin sering informasi melalui jalurjalur yang sama, maka semakin besar kemungkinan terjadinya perubahan. Perubahan struktural di sinaps (bagian sel saraf yang berfungsi sebagai penghubung antar sel) maupun perubahan biokimiawi merupakan hal yang mendasari inforamasi menuju long term memory atau memori jangka panjang.

Perubahan biokimiawi yang terjadi dalam otak akan memengaruhi kualitas ingatan seseorang. Kualitas ingatan ini dapat diketahui melalui alat tes prestasi yang merupakan suatu alat yang dapat digunakan untuk mengetahui sejauh mana kemajuan belajar yang telah dicapai oleh siswa. Tinggi rendahnya kualitas belajar siswa tidak lepas dari adanya faktor pengulangan maupun hambatan yang terjadi dalam belajar. Retensi terhadap materi bahasa Inggris antara 
ketiga kelompok tersebut dapat diketahui melalui tes prestasi yang telah disusun sebelumnya oleh guru yang bersangkutan. Berdasarkan hasil analisis, diperoleh data bahwa rata-rata siswa yang mendapatkan pengulangan materi dalam penelitian ini dikenal dengan istilah rehearsal memiliki nilai rata-rata yang lebih tinggi dibandingkan kelompok lain (Matematika atau interferensi dan kelompok kontrol). Rata-rata jawaban benar pada tes bahasa Inggris yang diperoleh kelompok rehearsal adalah 20,2, kelompok interferensi 13,2 dan kelompok kontrol 18. berikut penjelasannya.

Hebb (Solso dkk, 2008) mengatakan bahwa informasi dari short term memory akan dikirim ke long term memori apabila informasi tersebut diulangulang (rehearsed) di short term memory. Transformasi informasi dari short term memory ke long term memori tersebut terjadi karena struktur short term memory di otak memiliki sirkuit yang berisikan aktivitas-aktifitas neural yang bergema (reverberating), yang memiliki neuronneuron yang mampu bergerak dalam putaran (loop) secara mandiri. Manakala sirkuit tersebut tetap aktif dalam satu periode tertentu, terjadilah perubahan kimiawi dan atau perubahan struktural, dan memori disimpan secara permanen dalam long term memori. Jika informasi tersebut dikombinasikan dengan memorimemori lain yang bermakna, maka terjadilah peningkatan memorabilitas (kemudahan memori untuk diingat). Slavin (Alsa, 1996) mengatakan bahwa pengulangan secara mental terhadap informasi dapat meningkatkan retensi. Hal ini dibuktikan oleh nilai mean difference 2,20 antara kelompok eksperimen 1 (rehearsal) dengan kelompok kontrol. Dengan demikian, dapat disimpulkan bahwa rehearsal memiliki pengaruh yang lebih besar terhadap retensi dibandingkan dengan kelompok kontrol yang dibebaskan dari kegiatan apapun.

Selama penelitian berlangsung, kelompok kontrol dibebaskan dari segala macam kegiatan belajar atau diistirahatkan. Pada saat kelompok kontrol dibebaskan dari segala macam kegiatan belajar, peneliti mengamati bahwa mayoritas siswa menghabiskan waktu istirahatnya dengan tidur di kelas. Dahl (Djalali, Farid, \& Ayu, 2003) menyatakan bahwa tidur yang cukup ialah sejumlah waktu yang dibutuhkan oleh seseorang agar fungsi tubuh bekerja secara optimal. Banyak yang mengatakan bahwa kualitas tidur jauh lebih penting daripada jumlah waktu tidur. Menurut Graham (Djalali, Farid, \& Ayu, 2003), kelompok kontrol yang mengistirahatkan dirinya dengan tidur mendapat manfaat dari tidur itu sendiri, di antaranya adalah menjaga kemampuan memori, perhatian, atau konsentrasi serta emosi.

Kelompok kontrol masih menyimpan materi bahasa Inggris yang telah diajarkan sebelumnya. Hal ini dibuktikan dengan melihat hasil tes yang diperoleh antar kelompok penelitian. Kelompok kontrol memiliki retensi yang lebih tinggi 
dibandingkan kelompok eksperimen 2 (interferensi), namun lebih rendah jika dibandingkan dengan kelompok rehearsal. Retensi siswa yang lebih rendah jika dibandingkan dengan kelompok rehearsal dapat terjadi karena tidak ada pengulangan materi sekalipun siswa dapat menjaga ingatannya terhadap materi bahasa Inggris yang telah disampaikan sebelumnya. Means difference yang diperoleh antara kelompok kontrol terhadap kelompok ekperimen 1 (rehearsal) adalah -2,20 dengan kata lain rehearsal memiliki pengaruh yang lebih besar terhadap retensi dibandingkan kelompok kontrol.

Sebaliknya, informasi yang diperoleh tidak total karena adanya informasi lain yang masuk, yaitu matematika (interferensi) dan tidak mengalami pengulangan menyebabkan sel-sel saraf tidak dapat berkembang (Afiatin, 2001). Materi bahasa Inggris yang diterima oleh siswa tidak mendapatkan perhatian yang cukup karena adanya materi matematika dan menyebabkan materi yang masuk ke dalam ingatan tidak total atau hanya setengah-setengah. Materi bahasa Inggris yang diterima secara tidak total tersebut disebabkan adanya interferensi yang menyulitkan sel saraf untuk berkembang. Sel-sel saraf dapat tidak berkembang dengan baik karena tidak mendapatkan stimulasi berupa pengulangan materi bahasa Inggris. Informasi yang sudah tersimpan dalam memori berupa materi bahasa Inggris akan mengalami pencampuradukan dengan informasi lain yaitu materi matematika yang dipelajari oleh siswa. Informasi yang baru diterima siswa (meteri matematika) berpotensi mengganggu proses mengingat informasi yang diterima sebelumnya (materi bahasa Inggris).

Teori interferensi mengatakan bahwa kekuatan retensi seseorang bukan dipengaruhi lamanya interval waktu antara saat menerima informasi dan saat memanggil informasi tersebut, tapi lebih ditentukan oleh aktivitas yang dilakukan individu selama interval waktu tersebut (Sternberg, 2006). Aktivitas tersebut akan merusak atau mengganggu (interferensi) jejak ingatan sehingga memungkinkan individu akan mengalami lupa. Dalam sebuah penelitian disebutkan bahwa terjadi penurunan ingatan yang sangat tajam pada partisipan yang diminta mengingat trigram-trigram dengan interval 3, 6, 9, 12, 15, atau 18 detik setelah presentasi huruf terakhir. Dari penelitian tersebut dapat disimpulkan bahwa semakin banyak isi interval, maka semakin lemah retensi individu, demikian pula sebaliknya.

Menurut Thompson, Geoves, dan Rebec (Afiatin, 2001), perjalanan impuls dalam akson lebih cepat pada akson yang termielinisasi. Mielinisasi terjadi karena adanya stimulasi berupa pengulangan atau rehearsal. Semakin sering sebuah informasi diulang menyebabkan semakin banyak lapisan mielin yang mengelilingi 
akson. Dengan demikian semakin cepat informasi atau impuls dihantarkan dan semakin cepat pula terjadi saling hubungan antar sel-sel saraf sehingga jaringan koneksi yang terjalin juga semakin banyak.

Banyaknya jaringan koneksi yang terjalin melalui pengulangan dan latihan soal membantu siswa untuk lebih mudah membentuk konsep, mengaitkan apa yang dipikirkan, dan memecahkan masalahnya dalam belajar. Hal tersebut dapat dilihat melalui mean differences antara kelompok rehearsal dengan kelompok interferensi, di mana diperoleh nilai mean differences sebesar 6,99. Dengan kata lain rehearsal memiliki pengaruh yang lebih besar terhadap retensi dibandingkan interferensi.

Sebaliknya, semakin sedikit lapisan mielin yang mengelilingi akson karena adanya informasi baru yang tidak relevan, semakin tipis lapisan mielin yang mengelilingiakson, sehingga menghambat informasi dihantarkan. Penipisan ini dapat terjadi karena tidak adanya kegiatan atau informasi lain yang relevan dalam penelitian ini berupa pemberian materi matematika setelah materi bahasa Inggris. Keadaan ini memperlambat hubungan antar sel-sel saraf sehingga jaringan koneksi materi bahasa Inggris yang terjalin terbatas. Jaringan koneksi yang terbatas menyulitkan siswa untuk membentuk konsep, mengaitkan apa yang dipikirkan, dan memecahkan masalahnya dalam belajar. Hal tersebut dapat dilihat melalui mean differences antara kelompok rehearsal dengan kelompok interferensi, dimana diperoleh nilai mean differences sebesar -6,99. Dengan kata lain rehearsal memiliki pengaruh yang lebih besar terhadap retensi dibandingkan interferensi.

Mengapa kelompok kontrol memiliki retensi yang lebih tinggi dibandingkan kelompok interferensi? Selama penelitian berlangsung, kelompok kontrol dibebaskan dari segala macam kegiatan belajar atau diistirahatkan. Pada saat kelompok kontrol dibebaskan dari segala macam kegiatan belajar, peneliti mengamati bahwa mayoritas siswa menghabiskan waktu istirahatnya dengan tidur di kelas. Tidur rupanya membawa dampak tersendiri terhadap retensi.

Tidur yang dilakukan oleh kelompok kontrol mambantu individu untuk memfokuskan diri pada beberapa tugas yang akan diterimanya. Kecepatan dan efisiensi tindakan dapat meningkat. Sebuah studi manunjukkan bahwa cortex frontal, yakni wilayah otak yang paling aktif akan menjadi semakin aktif ketika seseorang terjaga dalam periode waktu yang panjang. Wilayah ini dapat kembali pulih selama tidur dan membuat orang merasa segar kembali setelah tidur, walaupun dengan waktu tidur yang pendek.

Dalam keadaan yang fresh seseorang akan lebih siap dalam menerima informasi baru atau dan dapat lebih fokus dalam mengerjakan tugas-tugas yang memerlukan kemampuan kognitif 
yang lebih tinggi. Hal tersebut dapat dilihat melalui mean differences antara kelompok kontrol dengan kelompok interferensi, di mana diperoleh nilai mean differences sebesar 4,79. Dengan kata lain kelompok kontrol memiliki pengaruh yang lebih besar terhadap retensi dibandingkan interferensi. Hal ini diperkuat oleh Butcher (Djalali, Farid, \& Ayu, 2003) yang menyatakan bahwa tidur merupakan bagian yang sangat esensial dalam pembentukan memori, sehingga kekurangan tidur memiliki dampak yang negatif karena dapat menghilangkan kemampuan mengingat dan mengulang informasi yang didapatkan.

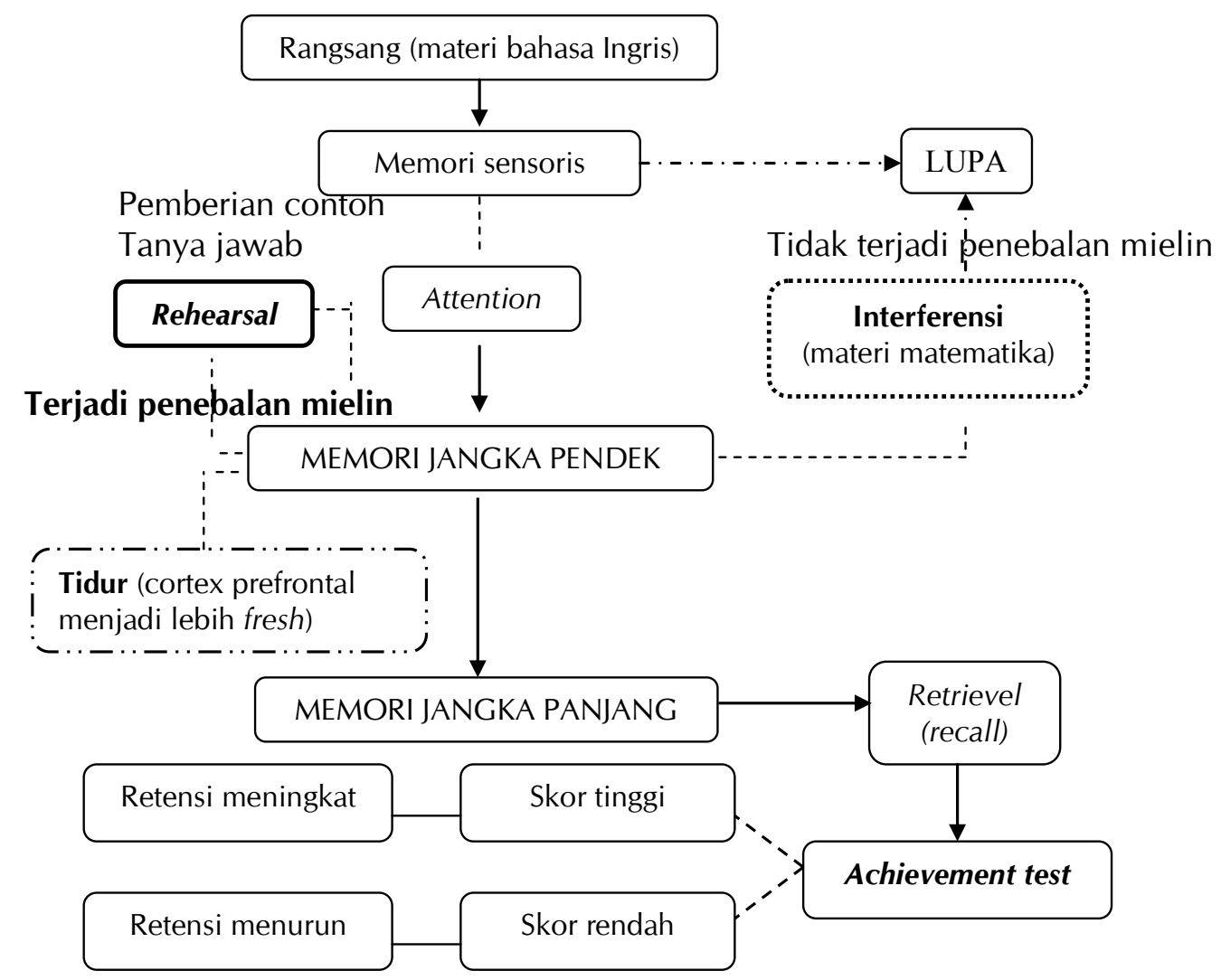

Keterangan:

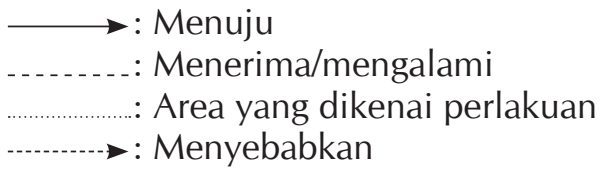

Gambar 1. Pengaruh Interferensi dan Rehearsal terhadap Retensi pada Tige Kelompok Penelitian 
Penelitian ini masih memiliki banyak sekali kelemahan dalam proses pengerjaannya. Beberapa kelemahan penelitian di antaranya adalah saat penyusunan soal. Tes prestasi yang telah disusun dan diujicobakan memiliki reliabilitas yang rendah. Hal ini dimungkinkan karena soal yang diujicobakan tersebut belum diajarkan oleh pihak sekolah sekalipun soal tersebut termasuk dalam silabus mata pelajaran. Selain itu, jenis soal yang terdiri dari tipe pilihan ganda, tipe benar salah dan tipe esai pun tak luput dari kelemahan penelitian ini. Pada soal dengan tipe pilihan ganda, ada kemungkinan jawaban benar yang dihasilkan merupakan kebetulan semata. Pada soal dengan tipe benar salah, tujuan dari soal ini adalah siswa mampu menganalisa komponen kalimat yang sudah ada lalu menentukan komponen kalimat tersebut sudah benar atu justru salah. Pada bagian ini, peneliti tidak menginstruksikan untuk menggarisbawahi kata yang salah atau menuliskan rumus yang benar pada jawaban benar, sehingga memungkinkan poin benar yang dihasilkan merupakan kebetulan semata. Pada tipe soal esai, soal yang diberikan terlalu sedikit yakni hanya lima soal dan dirasa kurang mewakili masing-masing materi. Pada akhirnya, tes prestasi yang telah disusun kurang peka untuk menunjukkan pengaruh interferensi dan rehearsal terhadap retensi bahasa Inggris, sehingga dihasilkan koefisien reliabilitas 0,28.

\section{SIMPULAN DAN SARAN}

\section{Simpulan}

Simpulan dari penelitian ini adalah ada perbedan rata-rata nilai pelajaran bahasa Inggris pada siswa kelas VIII antara siswa yang diberi interferensi dan siswa yang diberi rehearsal. Artinya, siswa yang diberi rehearsal memiliki retensi yang lebih tinggi pada mata pelajaran bahasa Inggris daripada siswa yang diberi interferensi. Dengan demikian, hipotesis penelitian yang diajukan sebelumnya dapat diterima.

\section{Saran}

Berdasarkan penelitian yang telah dilakukan dan hasil yang diperoleh, maka dengan ini penulis memiliki beberapa saran sebagai berikut:

\section{Subjek Penelitian}

Siswa sebaiknya rajin melakukan pengulangan materi yang dianggap sulit bersama teman sebaya atau kakak kelas agar mendapat arahan yang benar. Selain itu, dalam menghadapi ujian atau ulangan harian sebaiknya menghindari kegiatan belajar yang beruntun dan dikerjakan dalam waktu singkat. Sebaliknya, siswa mempersiapkan diri beberapa hari sebelum ujian untuk melakukan pengulangan pada materi yang akan diujikan. Jika siswa sudah merasa lelah dalam belajar, akan lebih baik jika siswa beristirahat untuk merefresh otaknya daripada 
melakukan kegiatan lain yang akan menyita perhatian karena hal tersebut dapat membuyarkan materi yang sudah dipelajari sebelumnya.

2. Pihak Sekolah

Sekolah merupakan tempat pembinaan siswa dalam belajar. Dalam lembaga ini diharapkan guru dapat menjalin kedekatan dengan siswa yang agar siswa tidak segan untuk bertanya atau meminta bimbingan pada materi-materi yang belum dipahami. Selain itu, dalam menyusun jadwal pengayaan atau ujian sebaiknya hindari penyusuanan jadwal yang bertumpuk dalam satu hari, terutama untuk pelajaran inti karena hal ini dimungkinkan dapat menjadi interferensi tersendiri bagi siswa.

3. Bagi Peneliti Selanjutnya

Bagi peneliti selanjutnya yang tertarik dengan topik yang relatif sama, maka ada beberapa saran yang dapat penulis berikan, antara lain:

a. Untuk respon jawaban dalam tes prestasi tersebut dapat dibuat bervariasi dengan komposisi yang variatif sesuai dengan kompetensi yang diinginkan.

b. Sebelum ujicoba sebaiknya tanyakan terlebih dahulu pada pihak sekolah tempat di mana akan dilakukan ujicoba apakah materi yang ada dalam alat tes tersebut sudah diajarkan atau belum agar diperoleh konsistensi yang lebih baik.

c. Untuk desain eksperimen, sebaiknya menggunakan rancangan eksperimental yang berbeda, yaitu pre-posttest design. Dengan menggunakan desain tersebut, selain dapat mengetahui pengaruh interferensi dan rehearsal, bisa juga diketahui seberapa banyak penurunan retensi dengan adanya interferensi dan seberapa besar peningkatan retensi dengan adanya rehearsal.

\section{DAFTAR PUSTAKA}

Afiatin, T. (2011). Belajar Pengalaman untuk Meningkatkan Memori. Jurnal Anima (1), 26-35.

Alsa, A. (1996). Studi Eksperimen tentang Pengaruh Interferensi dan Rehearsal terhadap Retensi pada Belajar Matematika Siswa Kelas V Sekolah Dasar. Jurnal Psikologi, 2, 55-66.

Djalali , M.A, Farid, M, \& Ayu, I.D. (2003). Pengaruh Kekurangan Tidur Terhadap Memori dan Emosi Pada Remaja. Jurnal Anima, 19 (1), 86-104. 
Kompas. (2012). Standar Kelulusan UN 2009 Jadi 5,5. Diakses dari situs http://megapolitan.kompas.com/ $\mathrm{read} / 2009 / 02 / 16 / 08082596 /$ Standar.Kelulusan.UN.2009.Jadi.5.5.

Priyatno, D. (2010). Paham Analisa Statistik Data dengan SPSS. Yogyakarta: Mediakom.

Santrock, J.W. (1983). Psikologi Perkembangan. Erlangga. Jakarta.
Seniati L, Yulianto, A., \& Setiadi, B.N . (2009). Psikologi Eksperimen. Jakarta: Indeks.

Solso, R., Maclin, O.H., \& Maclin, M.K. (2008). Psikologi Kognitif. Erlangga. Jakarta.

Sternberg, R.J. (2006). Cognitive Psychology, Fourth Edition (terjemahan). Yogyakarta: Pustaka Pelajar 